\title{
Speech Intelligibility and Subjective Evaluation of Music Playback of Sound Transducers with Glass and Wooden Membrane
}

\author{
Gy. Wersényi \\ Széchenyi István University, Department of Telecommunications \\ Egyetem tér 1, H-9026, Győr, Hungray \\ E-mail: wersenyi@sze.hu
}

Abstract: Novel state-of-the-art designer loudspeaker solutions offer "invisible audio" applications by applying a relatively small transducer onto glass or wooden plates, surfaces such as windows, tables, doors etc. Although manufacturers promise high quality transmission and good technical parameters, reliable measurement data do not exist. In our former evaluation, the SolidDrive system with glass membrane of different shapes, sizes, fixation methods was analyzed using vibration analysis, acoustic measurements and numerical simulations in COMSOL/FEM. This paper presents experimental results of standardized speech intelligibility measurements as well as subjective evaluation of the system.

Keywords: speech intelligibility, subjective evaluation, STI, sound transducer

\section{Introduction}

Loudspeakers in general are based on the same electromagnetic principle. A light weight membrane is moved by the coil oscillating in the magnetic field driven by the electric current. In order to avoid acoustic short circuits and to extend the frequency range, speakers are built into cabinets (closed, bass-reflex, loaded horn etc.). Newly designed solutions offer unconventional types of sound reproduction, often called "invisible audio" [1-3]. In this case, sound transducers of the same electromagnetic principle are manufactured and sold as stand-alone exciters without membranes. They can be attached to various surfaces, usually by gluing them on glass plates or screwing them on to wood, such as windows, tables, doors etc. This technique allows unique installations and applications by avoiding the need for large cabinets and by integrating the real sound source into or onto various equipment already installed in the environment. However, relatively low signal pressure levels (sensitivity), limited and unbalanced frequency response and high costs restrict their applicability to special needs, designer solutions and commercial purposes. Furthermore, manufacturers provide limited access to technical information and measurement results of technical parameters in their commercial literature, thus, it is difficult to decide whether a particular device is able to meet a customer's needs. The goal of our investigation was 
to test a commercially available transducer applied to various surfaces. This included vibro-acoustic measurements using multi-channel accelerometers, measurements of acoustic parameters and comparative evaluation based numerical simulation using FEM models in COMSOL [4,5]. As mentioned, there is only very limited technical information about the system. Most of the parameters cannot be measured without a membrane being attached to the transducer, so the general description of only the transducer of such systems - e.g. about frequency response or directional characteristics - does not provide reliably useful information. Acoustic and vibration measurements are time- and cost-expensive. Therefore, numerical simulations and FEM-based modelling seem to be an adequate alternative for estimating some of the technical parameters for real-life applications: the effect of membranes of different shapes, mass, material, fixing methods etc. can be evaluated without actual measurements.

The rest of the paper is organized as follows. Section 2 gives a short overview about the measurement setup including the objective and the subjective tests. Furthermore, the basic speech intelligibility tests are introduced for selection. Section 3 presents the results of the MRT, SIL and music transmission tests. Section 4 discusses the findings and future works will be highlighted in Section 5.

\section{Measurement setups}

\subsection{Objective evaluation and former results}

In our former study, in order to test the simulation method's reliability and the technical parameters in comparison the transducer was applied to various glass surfaces for vibration and acoustic measurements in parallel with a corresponding FEM simulation. Based on these studies, recommendations were given for applications comparing benefits and disadvantages [6-7]. These can be summarized as follows:

- Numerical simulation supports real measurement results, thus, estimations based on FEM modelling can be an alternative solution to measurements.

- Frequency response from $200 \mathrm{~Hz}-10 \mathrm{kHz}$ can be realized with almost plane wave propagation.

- The relatively low sensitivity limits the range of propagation and the SPL (nonlinear distortion).

- Placement of the transducer on the plate and fixation methods of the plane do not bias measurement results significantly.

- The system is not able to replace conventional loudspeaker setups if high quality playback is needed.

Figure 1 and 2 shows the SD1g transducer alone and applied on a glass membrane for the measurements. 


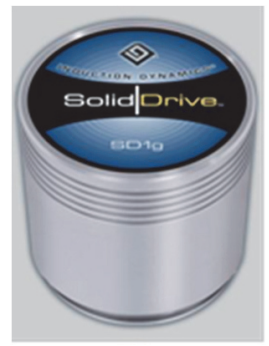

Figure 1. The SolidDrive SDIg transducer

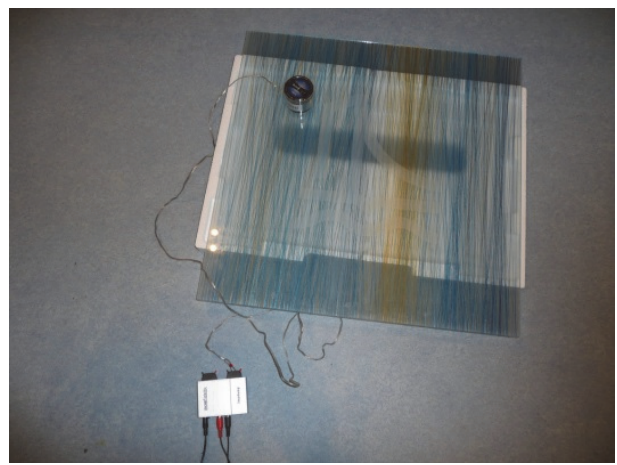

Figure 2. Initial setup for the transducer fixed on a glass plate and with a digital audio amplifier.

\subsection{Subjective evaluation}

Objective measures can predict musical and speech transmission quality of the system. Still, subjective evaluation of playback systems play a significant role in customers' judgments and selection criteria. The final step of this survey included the following evaluations:

- measurement of speech intelligibility (SI) based on standardized methods for German language in listening tests,

- estimation of the Speech Transmission Index (STI) based on Speech Interference Level (SIL) measurement and

- subjective evaluation of music playback with and without an additional subwoofer.

For the listening tests the following measurement setup was installed in an anechoic chamber. A formerly introduced glass plate of $76^{*} 76^{*} 0.8 \mathrm{~cm}$ (see Fig.2.) was placed on rubber legs in front of the listener. Simultaneously, another exciter of the same model was fixed by screws under the surface of a wooden table of $55 * 130 * 2.5 \mathrm{~cm}$. A Yamaha DSP-A2 audio amplifier and a studio monitor loudspeaker for reference were used. Subjects were sitting on a comfortable chair at the table facing the glass plate and a tilted computer screen. They could respond via the screen by clicking with a wireless 
mouse. Figure 3 shows the installation. Signal level at the listening position was set to be equal for all three radiators at $65 \mathrm{~dB}(\mathrm{~A}) \mathrm{L}_{\mathrm{eq}}$ using white noise. The level could be adjusted in $1 \mathrm{~dB}$ steps. 12 female and 20 male subjects participated between 16 and 35 years (mean 24) in 30-minute sessions.

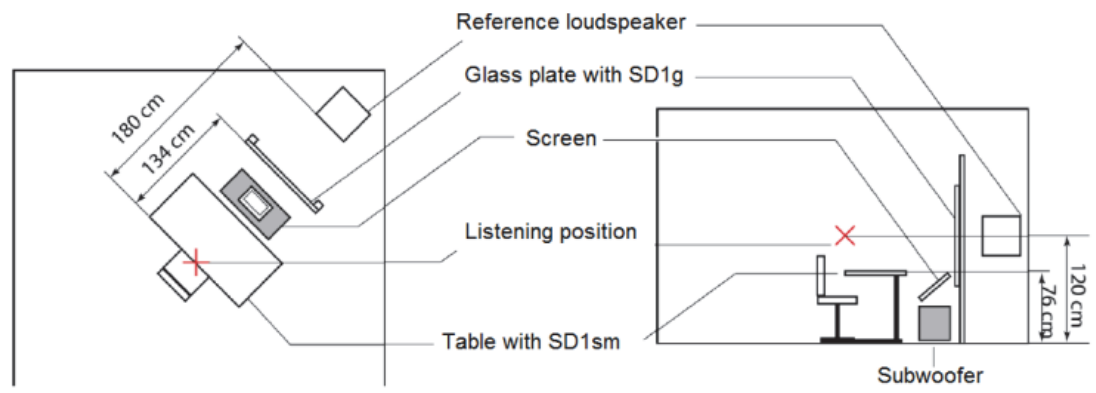

Figure 3. Schematic figure of the setup from above (left) and from the side (right).

For the music test, an additional closed-type subwoofer of 15 litres volume was installed under the table that could be switched on and off by the subject. One session included three one-minute tracks with 10 seconds of intermission. All three tracks were played back for every listener twice (on glass and on wood). These three tracks were selected to represent different bass content, characteristics and tonality of female voices. balance)

Track1: Lena Mayer Landrut - "I like to bang my head" (bass and voice in

Track2: Katie Melua - "Spider’s web” (more voice)

Track3: Drum/percussion recording (more bass, no voice)

Figure 4 shows the transfer characteristics of the wooden table with and without subwoofer support. As expected, the low frequency region between $30-80 \mathrm{~Hz}$ can be amplified by the subwoofer.

\subsection{Speech Intelligibility}

Speech intelligibility (SI) can be measured with different methods, usually in the frame of room acoustics and clinical audiology [8-10]. SI is a number between $0-100 \%$ and it is different for one syllable, multiple syllable words or sentences. The quality of the speech signal, transmission, subject group etc. also influence the results. Subjective tests can be 'open' where perceived words have to be repeated by the listener or 'closed' where listeners select from a collection of possibilities (forced choice). Table 1 shows comparative summary of different measurement methods corresponding to subjective levels on the left. In medical audiology only subjective testing methods are used targeting the determination of the speech intelligibility threshold, that is, the SPL (dB) where intelligibility is $50 \%$. 
Table 1. Comparison of different SI measurement methods (DIN EN ISO 9921-2003). Corresponding to the best STI level, a 98\% rate of a MRT is needed.

\begin{tabular}{|c|c|c|c|c|c|}
\hline Classification & $\begin{array}{c}\text { Sentence } \\
(\mathbf{\%})\end{array}$ & $\begin{array}{c}\text { Words, } \\
\text { MRT } \\
(\mathbf{\% )}\end{array}$ & $\begin{array}{c}\text { CVC Words } \\
\text { (no meaning) } \\
(\mathbf{\%})\end{array}$ & STI & $\begin{array}{c}\text { SIL } \\
\text { (dB) }\end{array}$ \\
\hline excellent & 100 & $>98$ & $>81$ & $>0,75$ & 21 \\
\hline good & 100 & $93-98$ & $70-81$ & $0,60-0,75$ & $15-21$ \\
\hline acceptable & 100 & $80-93$ & $53-70$ & $0,45-0,60$ & $10-15$ \\
\hline poor & $70-100$ & $60-80$ & $32-53$ & $0,30-0,45$ & $3-10$ \\
\hline insufficient & $<70$ & $<60$ & $<31$ & $<0,30$ & $<3$ \\
\hline
\end{tabular}
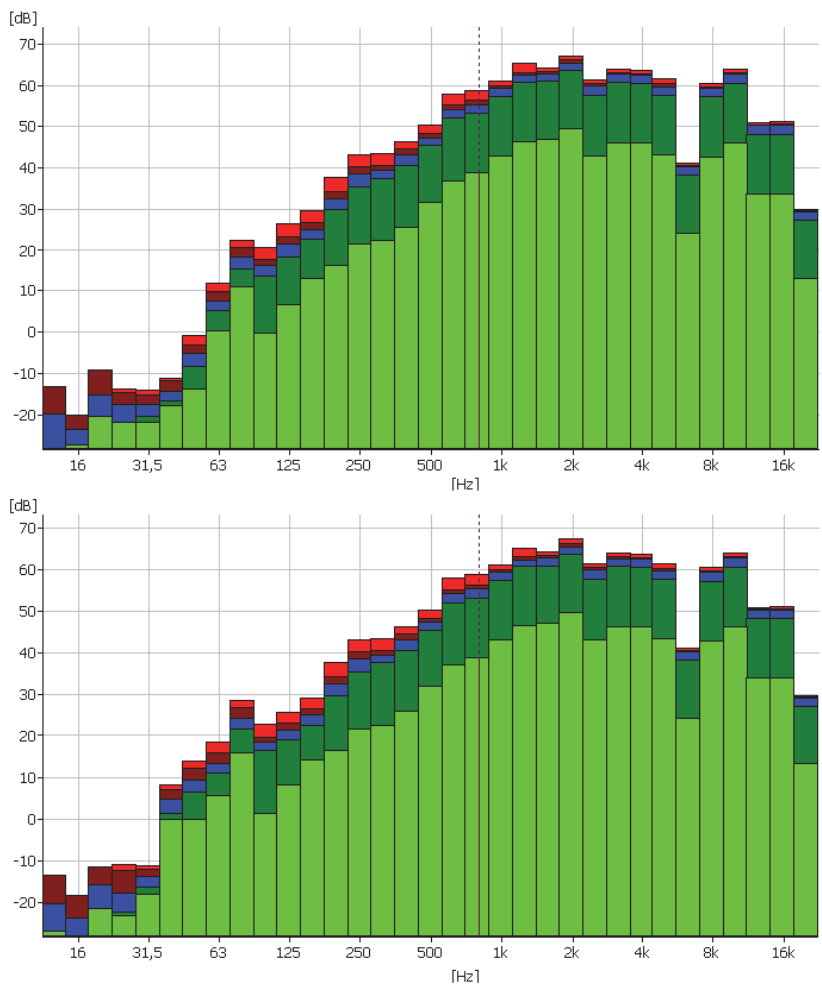

Figure 4. Transfer characteristics of the exciter fixed on the wooden table without (upper) and with subwoofer support (lower). The frequency range between 30-80 $\mathrm{Hz}$ is elevated.

Several standardized tests exist for subjective measurement for German language, for example the Freiburger test uses 20 one-syllable words and 10 lists containing 10 numbers [11,12]; the Marburger test for children [13,14]; the Göttinger test with meaningful sentences created from 5 words $[15,16]$ or the Oldenburger test with meaningless sentences [16-18]. Based on different considerations and limitations of the measurement system and procedure the so called Modified Rhyme Test (MRT) was selected for the subjective evaluation [19,20]. It uses six-word lists of rhyming or 
similar-sounding monosyllabic words. Each word is constructed from a consonantvowel-consonant (CVC) sound sequence, and the six words in each list differ only in the initial, the final consonant sound or the vowel. Listeners are shown a six-word list and then asked to identify which of the six was spoken. A carrier sentence can be also used. MRT test results indicate errors in discrimination of both initial and final consonant sounds. Listener responses can be scored as (1) the number of words heard correctly, (2) the number of words heard incorrectly or (3) the frequency of particular confusions of consonant sounds. Examples for German, English and Hungarian MRT lists can be seen in the appendix. In our test, the German database was used assisted by a user interface from the University of BTU Cottbus that is free to download [21]. Figure 5 shows a screen-shot of the application. For recording the speech database, all words were read seven times by a native German male speaker and the best examples were selected for the test after normalizing the levels. Every subject received a 24-word list four times, using glass and wood, and with a low and a high presentation level respectively.

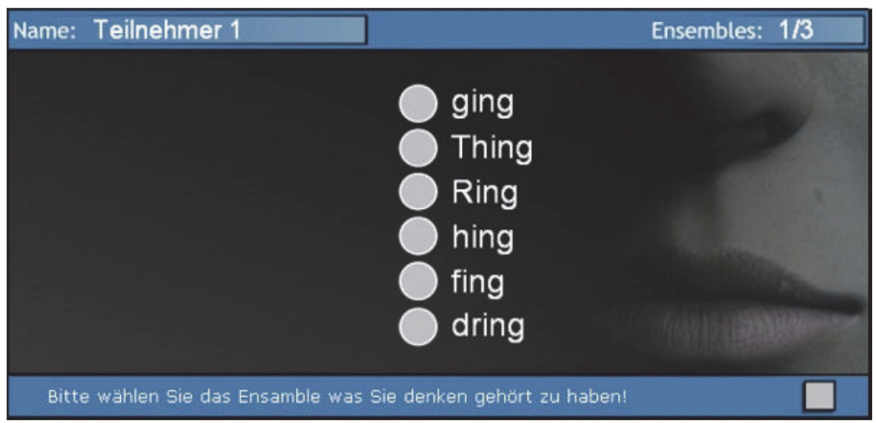

Figure 5: Screenshot of the Simasoft application [21]. The application has also built-in statistics for SI and weighted SI.

There is also a language independent objective measurement for speech intelligibility estimation, called Speech Transmission Index (STI) and Speech Interference Level (SIL) [22-28]. For the STI measurement, loudspeakers and microphones are needed. Excitation signals contain seven octaveband noises between $125 \mathrm{~Hz}$ and $8000 \mathrm{~Hz}$, amplitude modulated by a modulation signal of $0,63-12,5 \mathrm{~Hz}$. The STI is recommended if the transmission properties of the playback system and background noise, echo have to be taken in account. In case of room reverberation time less than one second, the STI can be calculated from the measured SIL as follows:

$$
4 \mathrm{STI}=(0,1 \mathrm{SIL}+0,9)
$$

For the SIL measurement the same pre-recorded speech signals were used. During the measurement, a presentation level varying from 20 to $65 \mathrm{~dB}$ was set and the resulting STI estimation was plotted directly. Due to the anechoic environment in our measurement setup, the STI could be calculated based on the SIL measurement. 


\section{Results}

\subsection{Modified Rhyme Test}

For the MRT test, the German wordlist was selected (see Appendix). In contrast to the English test and other wordlists, this contains 5-word sub-lists. In order to reduce the probability of guessing in case of misunderstanding, the sixth possibility was set to "no answer". In the case of 6-word lists, subjects click an answer if they are not sure with a probability of $1 / 6$. Thus, results are usually re-calculated and weighted using different methods. In our case, this was avoided by introducing this sixth possibility. For control purposes, a short white noise signal was also played back randomly in the tests. During the test 1691 false answers were recorded and from this subjects selected "no answer" only 686 times. On the other hand, if the white noise sample was used, subjects never clicked any of the word options, so white noise was really easy to detect.

Table 2 shows mean values and standard deviations for all three radiators for the initial, final consonant and the vowel. The last column shows the weighted (corrected) values. The relatively large standard deviation is due to the short wordlist and low presentation level.

Table 2. Mean and STDV values for all three radiators for high presentation level (top) where intelligibility is between 50-100\% and for low presentation level (bottom) where intelligibility is lower than 50\%. LS is studio reference monitor, SDg is a glass and

SDh, a wooden membrane.

\begin{tabular}{|c|c|c|c|c|c|}
\hline & SI (\%) & initial & middle & final & Weighted SI \\
\hline LS & \multirow[t]{3}{*}{ Mean } & 55,56 & 84,58 & 64,61 & 68,25 \\
\hline $\mathrm{SDg}$ & & 67,35 & 83,91 & 67,84 & 73,04 \\
\hline $\mathrm{SDh}$ & & 66,74 & 88,94 & 68,64 & 74,77 \\
\hline LS & \multirow[t]{3}{*}{ Stdv } & 22,57 & 18,45 & 20,66 & 40,80 \\
\hline $\mathrm{SDg}$ & & 19,23 & 18,53 & 18,85 & 10,49 \\
\hline $\mathrm{SDh}$ & & 18,46 & 11,24 & 18,49 & 10,21 \\
\hline LS & \multirow[t]{3}{*}{ Mean } & 17,55 & 47,93 & 26,26 & 30,58 \\
\hline $\mathrm{SDg}$ & & 9,06 & 44,30 & 19,81 & 24,39 \\
\hline SDh & & 23,03 & 42,60 & 29,29 & 38,24 \\
\hline LS & \multirow[t]{3}{*}{ Stdv } & 14,23 & 21,50 & 17,59 & 11,95 \\
\hline $\mathrm{SDg}$ & & 14,56 & 28,32 & 17,67 & 13,25 \\
\hline $\mathrm{SDh}$ & & 22,70 & 23,15 & 16,48 & 14,20 \\
\hline
\end{tabular}

If the presentation level is high enough for the weighted SI to be greater than $50 \%$, the vowel component can be recognized easily. Furthermore, there is no significant 
difference between the initial and final consonants. Comparing weighted SI values of $73,04 \%$ with $74,77 \%$ there is no benefit for any of the SD transducers and the results are only slightly below the results of the studio reference loudspeaker. If presentation level is low and SI is below 50\%, differences become greater. Although the vowel can be recognized the best, rates are much lower than previously. Furthermore, the final consonant can be recognized better than the initial one, especially with glass. The summarized comparison shows a much better performance for the weighted SI using wood $(38,24 \%)$ than glass $(24,39 \%)$. Wood was even superior to the reference loudspeaker.

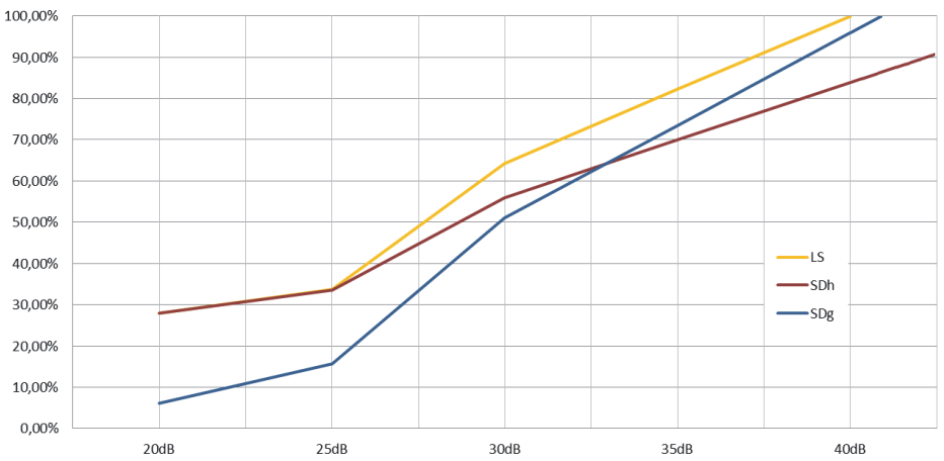

Figure 6. SI as function of presentation level of the reference loudspeaker (yellow), transducer on glass (blue) and transducer on wood (red).

Using all radiators in the MRT, the $98 \%$ intelligibility rate could be achieved using wood as membrane at $45 \mathrm{~dB}(\mathrm{~A})$ SPL and using glass at $41 \mathrm{~dB}(\mathrm{~A})$ indicating no significant difference between these mediums (Fig. 6).

\subsection{SIL measurement}

During the objective measurement, the SIL (and thus, the STI) increases rapidly as SPL increases from $20 \mathrm{~dB}(\mathrm{~A})$ to $65 \mathrm{~dB}(\mathrm{~A})$. An STI of 0,75 is reached at $47 \mathrm{~dB}(\mathrm{~A})$.

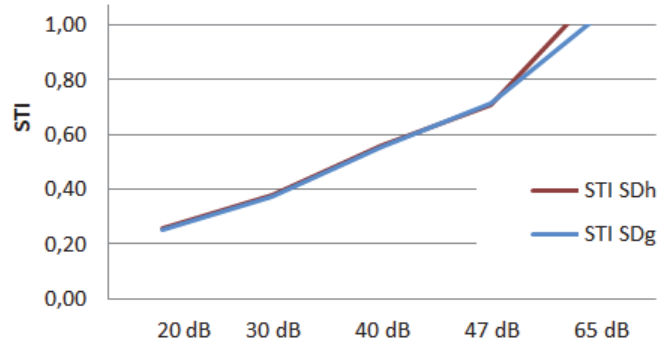

Figure 7. Curves of SLI transformed to STI values as function of presentation level.

At higher presentation levels, wood performed somewhat better than glass. As expected, standard deviations are higher at lower signal levels. Both SIL and calculated STI increase rapidly above $30 \mathrm{~dB}(\mathrm{~A})$. These results are in agreement with the MRT results. 


\subsection{Music transmission}

The evaluation of overall music transmission quality was based on a ranking in five steps where 1 point corresponds to "insufficient", 2 to "poor", 3 to "acceptable", 4 to "good" and 5 to "excellent". Bass transmission, however, used only three steps from 1 to 3 points.

In overall quality based on all tracks, glass was superior to wood, being "above average" for about $70 \%$ of the listeners. The same evaluation for wood showed a result of $45 \%$ and "average" was selected most frequently.
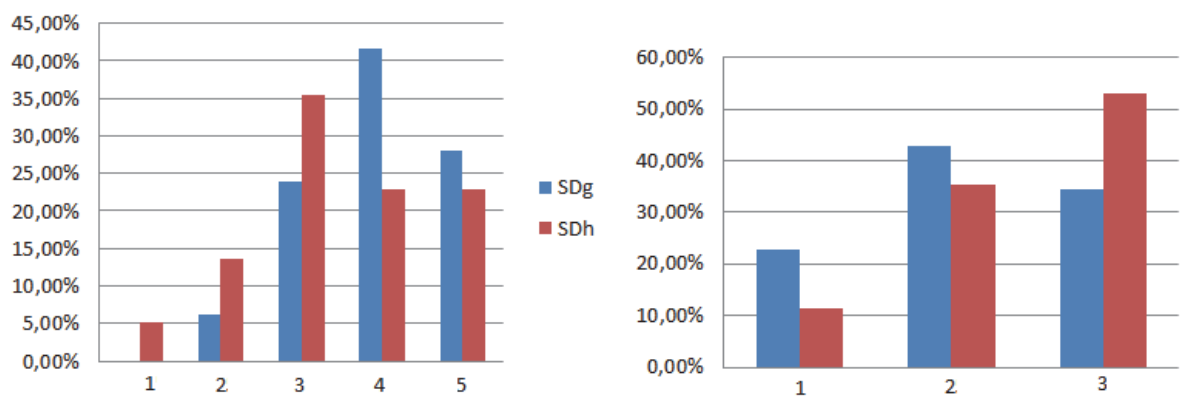

Figure 8. Relative frequency of answers for overall quality (left) and for bass transmission (right) for glass (blue) and wood (red).

In bass quality wood was superior to glass without subwoofer support. Wood was classified as excellent for about $52 \%$ as long glass was only for $33 \%$. $45 \%$ of the listeners would suggest subwoofer extension in case of wood, and $60 \%$ would suggest it in case of glass. Asking an informal question, users suggested they would even pay extra money to have subwoofer extension. Results depend on the tracks: more bass content in the music (track3) reveals the subjective need for subwoofer support.

\section{Discussion}

Speech intelligibility tests usually target subjects instead of equipment. This means, one subject will be evaluated using different presentation methods of speech samples, so focus is on the abilities of the subject. In our case the opposite happens, the sound transmission quality of a transducer was evaluated by several subjects for whether or not it is able to produce good speech and music transmission.

In the subjective MRT wood performed better than glass if the signal level (thus, the signal-to-noise ratio) was low. With an appropriate signal level, both performed almost equally as well and the studio reference loudspeaker in the anechoic environment. The $98 \%$ SI could be reached around 40-45 dB signal level and also the estimated STI for excellent values was around $47 \mathrm{~dB}$. In summary, for speech transmission, a signal-tonoise ratio greater than $50 \mathrm{~dB}$ would result in a sufficient SI supporting the manufacturer's claim.

There was also no significant difference between the membranes during music playback. Although they produce relatively low sound pressure levels and they cannot 
overperform high quality loudspeakers, it is an acceptable option for short distance radiation, such as sitting at a table or near to a window. Using a subwoofer extension may increase the subjective impression further.

It was interesting that subjects reported to be able to detect the location of the transducer on the vibrating plate. They could actually hear where the transducer was placed (screwed) on the table from below. However, this fact did not influence their judgments.

Although not used in the current evaluation, the Hungarian word list was developed based on the German test. In order to represent the relative frequency of the consonants and vowels related to Hungarian language word lists shorter than 5 words are also included. A test using this list, however, would need different presentation and evaluation methods as it differs from the usual MRT lists.

Beside the numerous advantages of this loudspeaker system, some disadvantages have to be listed as well. Independent of the membrane's material we get high costs, low sound pressure levels, fluctuating transfer function and low transmission below $200 \mathrm{~Hz}$ and above $12 \mathrm{kHz}$. Although not measured directly, if the radiated sound was set to "comfortably loud", non-linear distortions of the transducer and the vibrating surface become audible. The vibrating transducer can be easily overdriven. Furthermore, installation of multiple transducers on the same surface can have unexpected effects due to interferences, standing waves etc., and stereo or multi-channel transmission may not be applicable.

\section{Future work}

Future work includes comparative evaluation of intelligibility of German and Hungarian speech samples. It is expected that using the same testing method no significant difference will appear, that is, databases of results can be merged and evaluated combined, furthermore, that the Hungarian corpus for this test can be used in other similar tests in the future. The sound data base containing these words will be recorded by a native Hungarian speaker as high quality mono sound samples.

As an informal study, future work includes the system installed for a longer time period on a shop-window in a crowded pedestrian zone in the city center. The window will be used as membrane "speaking" to pedestrians and customers, airing some kind of commercial. Shop assistants and customers will be interviewed about this potential solution.

\section{Conclusion}

Transmission quality of sound transducers applied on wooden and glass membranes was evaluated based on objective and subjective measures. The objective measurement included a SIL measurement installed in the anechoic chamber. From this, STI estimation could be made resulting in a satisfactory value of greater than 0,75 in case of a presentation level of more than $47 \mathrm{~dB}$. The subjective evaluation using the modified rhyme test in German language supported these results as $98 \%$ of SI could be reached at $41 \mathrm{~dB}$ and $45 \mathrm{~dB}$ respectively. It can be concluded that an overall signal presentation level about 45-50 dB greater than background noise could be sufficient in non anechoic 
environments as well. This signal-to-noise ratio can be achieved in indoor environments.

Using three different one-minute music samples of different genres and bass content, both membranes were judged as average or better for music transmission even without an additional subwoofer support. Although glass performed somewhat better in overall music quality than wood, focusing on bass transmission, wood was better. A subwoofer extension for a better bass quality is suggested.

This study was aimed at a subjective evaluation that extended former objective acoustic and vibration measurements and numerical simulations. Summarized results support the manufacturer's recommendations and measurement results by offering alternative sound production solution if "invisible audio" issues are present.

\section{Acknowledgement}

This research was realized in the frames of TÁMOP 4.2.4. A/2-11-1-2012-0001 „National Excellence Program - Elaborating and operating an inland student and researcher personal support system" The project was subsidized by the European Union and co-financed by the European Social Fund.

\section{References}

[1] http://www.feonic.com/ (date of access: 2014.05.01)

[2] http://www.powerview.com/GlassResonator.html (date of access: 2014.05.01)

[3] http://www.soliddrive.com/ (date of access: 2014.05.01)

[4] http://www.comsol.com/ (date of access: 2014.05.01)

[5] Piacsek, A. A., Muehleisen, R. T.: Using COMSOL multiphysics software to investigate advanced acoustic problems, J. Acoust. Soc. Am., vol. 130, no. 4, pp. 2363-2363, 2011

[6] Wersényi, Gy.: Evaluation of Vibrating Sound Transducers with Glass Membrane Based on Measurements and Numerical Simulations, AES Convention Paper 8675, AES 132nd Convention, Budapest, Hungary, 2012

[7] Wersényi, Gy., Répás, J.: Practical recommendations for using sound transducers with glass membrane as auditory display based on measurements and simulations, Proc. of 19th International Conference on Auditory Display (ICAD 13), Lodz, Poland, pp. 153-156, 2013

[8] Döhler, S.: Bewertung der Sprachverständlichkeit von „Invisible-Audio“Lautsprechern auf Glas und Holz, BSc thesis, Hochschule für Telekommunikation Leipzig, 2014

[9] Fellbaum, K.: Sprachverarbeitung und Sprachübertragung. Springer-Verlag Berlin Heidelberg, 2012

[10]Kollmeier, B., Wesselkamp, M.: Development and evaluation of a German sentence test for objective and subjective speech intelligibility assessment, J. Acoust. Soc. Am., vol. 102, pp. 2412-2421, 1997

[11] Sukowski, H., Brand, T., Wagener K. C., Kollmeier, B.: Untersuchung zur Vergleichbarkeit des Freiburger Sprachtests mit dem Göttinger Satztest und dem Einsilber-Reimtest nach von Wallenberg und Kollmeier, HNO, vol. 57, Springer Medizin Verlag, pp. 239-250, 2008 
[12]Bangert, H.: Probleme bei der Ermittlung des Diskriminationsverlustes nach dem Freiburger Sprachtest, Audiol. Akustik, vol. 19, pp. 166-170, 1980

[13] Welzl-Müller, K.: Influence of Disturbing Noise on Sentence Intelligibility, Laryngo-Rhino-Otol, vol. 60, no. 3, pp. 117-120, 1981

[14] DIN 45621

[15] Klenzner, T., Stecker, M., Marangos, N., Laszig, R.: Zur Indikationserweiterung des ,cochlear-implant“ Freiburger Ergebnisse bei Patienten mit Resthörigkeit, HNO, vol. 47, no. 2, pp. 95-100, Feb. 1999

[16] Wagener, K., Kollmeier, B.: Göttinger und Oldenburger Satztest, Z. Audiol., vol. 43, pp. 134-141, 2004

[17] hoertech.hausdeshoerens-oldenburg.de/web/dateien/Bedienungsanleitung.wako.pdf

[18] Wesker, T., Meyer, B., Wagener, K., Anemüller, J., Mertins, A., Kollmeier, B.: Oldenburg Logatome Speech Corpus (OLLO) for Speech Recognition Experiments with Humans and Machines, Proc. of Interspeech 2005, pp. 1273-1276, 2005

[19] Wallenberg, E.-L. von, Kollmeier, B.: Sprachverständlichkeitsmessungen für die Audiologie mit einem Reimtest in deutscher Sprache: Erstellung und Evaluation von Testlisten, Audiol. Akustik, vol. 28, pp. 50-65, 1989

[20] Fairbanks, G.: Test of Phonemic Differentiation: The Rhyme Test, J. Acoust. Soc. Am., vol. 30, pp. 596, 1958

[21] http://www.siemasoft.de/programme/toolsutilities/reimtest/index.php (date of access: 2014.05.01)

[22] Williams, C. E., Hecker, M. H. L.: Relation between Intelligibility Scores for Four Test Methods and Three Types of Speech Distortion, J. Acoust. Soc. Am., vol. 44, pp. 1002, 1968

[23] Brungart, D. S.: Evaluation of speech intelligibility with the coordinate response measure, J. Acoust. Soc. Am., vol. 109, pp. 2276, 2001

[24] Tang, S. K., Yeung, M. H.: Reverberation times and speech transmission indices in classrooms, Journal of Sound and Vibration, vol. 294, no. 3, pp. 596-607, 2006

[25] Galbrun, L., Kitapci, K.: Accuracy of speech transmission index predictions based on the reverberation time and signal-to-noise ratio, Applied Acoustics, vol. 81, pp. $1-14$, July 2014

[26]Lazarus, H.: New methods for describing and assessing direct speech communication under disturbing conditions, Environment International, vol. 16, no. 4-6, pp. 373-392, 1990

[27] DIN EN 60268-16

[28] DIN EN ISO 9921

[29] http://alpha.tmit.bme.hu/speech/hdbbabel.php (date of access: 2014.05.01) 


\section{Appendix}

Examples of the German, English and Hungarian rhyme test corpus can be found in Table 3-7. The Hungarian version was created based on similarly to the German version according to the Hungarian speech databases and distribution values of the vocals [29]. Because some rare vocals could not be represented in equal number to the most frequent ones, some lines and examples may contain fewer words than the German version. This Hungarian word list can be used as a test material for further measurements and test.

Table 3. Wordlist of the German 'WAKO' one-syllable rhyme test used for the tests [29]

\begin{tabular}{|c|c|c|c|c|c|c|c|c|c|c|c|}
\hline Nr. & & Anla & autteil & & & & & Vol & calteil & & \\
\hline 1 & Sinn & & bin & Zinn & Kinn & 34 & schief & Schiff & Schaf & schaff & schuf \\
\hline & fiel & schiel & Ziel & Kiel & Nil & 35 & Mehl & Mal & & Mull & Müll \\
\hline $\begin{array}{l}3 \\
4\end{array}$ & $\begin{array}{l}\text { doch } \\
\text { sehn }\end{array}$ & $\begin{array}{l}\text { poch } \\
\text { den }\end{array}$ & $\begin{array}{l}\text { noch } \\
\text { Gen }\end{array}$ & $\begin{array}{l}\text { Joch } \\
\text { zehn }\end{array}$ & $\begin{array}{l}\text { Loch } \\
\text { lehn }\end{array}$ & $\begin{array}{l}36 \\
37\end{array}$ & $\begin{array}{l}\text { Wild } \\
\text { Wind }\end{array}$ & $\begin{array}{l}\text { Wald } \\
\text { Wand }\end{array}$ & wählt & Welt & wühlt \\
\hline 5 & wisch & Fisch & Tisch & zisch & misch & 38 & bis & $\mathrm{BaB}$ & Bus & büß & bös \\
\hline 6 & Saum & Schaum & nZaum & kaum & Raum & 39 & seht & Saat & satt & sät & Süd \\
\hline 7 & wir & vier & Pier & Tier & mir & 40 & hin & Hahn & Hohn & Huhn & höhn \\
\hline 8 & sahn & Bahn & Zahn & mahn & Lahn & 41 & wieg & Weg & wag & wog & wäg \\
\hline 9 & sät & tät & näht & jät & räı & 42 & hier & Heer & Haar & Herr & hör \\
\hline 10 & hieß & dies & gies & nies & ließ & 43 & Kien & Kinn & Kahn & kenn & kühn \\
\hline 11 & sehr & Teer & zehr & Meer & leer & 44 & dir & der & Dur & dürr & dörr \\
\hline 12 & Wut & gut & Nut & Ruth & lud & $\begin{array}{l}45 \\
46\end{array}$ & $\begin{array}{l}\text { biet } \\
\text { liea }\end{array}$ & bitt & Beet & Bett & böt \\
\hline 13 & Tag & mag & nag & jag & rag & $\begin{array}{l}46 \\
47\end{array}$ & $\begin{array}{l}\text { lieg } \\
\text { viel }\end{array}$ & $\begin{array}{l}\text { leg } \\
\text { fehl }\end{array}$ & $\begin{array}{l}\text { lag } \\
\text { Fall }\end{array}$ & $\begin{array}{l}\text { Leck } \\
\text { Fell }\end{array}$ & $\begin{array}{l}\text { lüg } \\
\text { füll }\end{array}$ \\
\hline 14 & vor & gor & Tor & Moor & Rohr & 48 & Ritt & Reet & rot & rät & rett \\
\hline 15 & weil & Šeil & peil & Teil & Zeil & 49 & Sinn & sehn & sann & Sohn & Senn \\
\hline $\begin{array}{l}16 \\
17\end{array}$ & $\begin{array}{l}\text { Haus } \\
\text { Schein }\end{array}$ & $\begin{array}{l}\text { Gauß } \\
\text { dein }\end{array}$ & $\begin{array}{l}\text { paus } \\
\text { mein }\end{array}$ & $\begin{array}{l}\text { raus } \\
\text { nein }\end{array}$ & $\begin{array}{l}\text { Laus } \\
\text { rein }\end{array}$ & 50 & Stiel & still & Stahl & Stall & stell \\
\hline 18 & war & gar & Kar & $\begin{array}{l}\text { nein } \\
\text { Jahr }\end{array}$ & rar & 52 & $\begin{array}{l}\text { Irleb } \\
\text { back }\end{array}$ & $\begin{array}{l}\text { Trip } \\
\text { Bock }\end{array}$ & $\begin{array}{l}\text { trapp } \\
\text { bück }\end{array}$ & $\begin{array}{l}\text { Trupp } \\
\text { böq }\end{array}$ & $\begin{array}{l}\text { trüb } \\
\text { Böck }\end{array}$ \\
\hline 19 & weiß & beiß & Geiß & Reis & leis & 53 & schiel & Schill & Schall & scholl & schäl \\
\hline 20 & fad & bat & Tat & Naht & Rat & 54 & Mist & Most & mußt & meBt & müBt \\
\hline $\begin{array}{l}21 \\
22\end{array}$ & $\begin{array}{l}\text { Fund } \\
\text { vorn }\end{array}$ & $\begin{array}{l}\text { Schund } \\
\text { Born }\end{array}$ & $\begin{array}{l}\text { Hund } \\
\text { Dorn }\end{array}$ & $\begin{array}{l}\text { Mund } \\
\text { Zorn }\end{array}$ & $\begin{array}{l}\text { rund } \\
\text { Korn }\end{array}$ & $\begin{array}{l}55 \\
56\end{array}$ & $\begin{array}{l}\text { Rist } \\
\text { trief }\end{array}$ & $\begin{array}{l}\text { Rost } \\
\text { triff }\end{array}$ & $\begin{array}{l}\text { Rest } \\
\text { traf }\end{array}$ & $\begin{array}{l}\text { rüst } \\
\text { trofff }\end{array}$ & $\begin{array}{l}\text { röst } \\
\text { Treff }\end{array}$ \\
\hline 23 & wumm & summ & dumm & Mumm & Rum & 57 & sind & sehnt & Sand & Sund & send \\
\hline 24 & Sicht & dicht & Gicht & nicht & Licht & 58 & Hieb & heb & hob & Hub & hupp \\
\hline 26 & SchuB & Bus & GuB & Kuß & NuB & & & Aus & autteil & & \\
\hline $\begin{array}{l}27 \\
28\end{array}$ & wenn & Fenn & $\begin{array}{l}\text { schind } \\
\text { denn }\end{array}$ & nenn & $\begin{array}{l}\text { Rind } \\
\text { renn }\end{array}$ & 59 & reif & reib & reit & Reim & Rhein \\
\hline 29 & säng & häng & peng & meng & läng & 60 & Muff & muB & Mumm & murr & Mull \\
\hline 30 & was & $\mathrm{HaB}$ & das & $P a B$ & $n a \beta$ & 61 & Mief & mies & miet & $\operatorname{mim}$ & mir \\
\hline 31 & Fest & best & Test & Nest & Rest & 62 & Weg & wem & wen & Wehr & web \\
\hline 32 & wann & dann & Tann & Mann & $\operatorname{ran}$ & 63 & nach & Naab & Naht & & nahm \\
\hline 33 & & & & Nacht & Jacht & $\begin{array}{l}64 \\
65\end{array}$ & $\begin{array}{l}\text { Ruf } \\
\text { rauf }\end{array}$ & $\begin{array}{l}\text { Ruß } \\
\text { raus }\end{array}$ & $\begin{array}{l}\text { Ruch } \\
\text { Rauch }\end{array}$ & $\begin{array}{l}\text { Ruhm } \\
\text { Raub }\end{array}$ & $\begin{array}{l}\text { Ruhr } \\
\text { Raum }\end{array}$ \\
\hline & & & & & & 66 & Los & Lob & & & Lohn \\
\hline & & & & & & 68 & $\begin{array}{l}\text { des } \\
\text { Saat }\end{array}$ & $\begin{array}{l}\text { Depp } \\
\text { sag }\end{array}$ & $\begin{array}{l}\text { Deck } \\
\text { sahn }\end{array}$ & $\begin{array}{l}\text { damm } \\
\text { Saar }\end{array}$ & $\begin{array}{l}\text { denn } \\
\text { Saal }\end{array}$ \\
\hline & & & & & & 69 & schief & schieB & schied & schien & schiel \\
\hline & & & & & & 70 & Graf & grab & Grat & Gram & Gral \\
\hline & & & & & & 71 & weiß & Weib & weit & Wein & weil \\
\hline & & & & & & 72 & Hof & hoch & hob & Hohn & hohl \\
\hline
\end{tabular}


Table 4. The 300 Stimulus Words of the MRT

\begin{tabular}{|c|c|c|c|c|c|c|}
\hline$\overline{11}$ & went & sent & bent & dent & tent & rent \\
\hline 2 & hold & cold & told & fold & sold & gold \\
\hline 3 & pat & pad & pan & path & pack & pass \\
\hline 4 & lane & lay & late & lake & lace & lame \\
\hline 5 & kit & bit & fit & hit & wit & sit \\
\hline 6 & must & bust & gust & rust & dust & just \\
\hline 7 & teak & team & teal & teach & tear & tease \\
\hline 8 & $\operatorname{din}$ & dill & $\operatorname{dim}$ & dig & dip & did \\
\hline 9 & bed & led & fed & red & wed & shed \\
\hline 10 & pin & $\sin$ & tin & fin & din & win \\
\hline 11 & dug & dung & duck & dud & dub & dun \\
\hline 12 & sum & sun & sung & sup & sub & sud \\
\hline 13 & seep & seen & seethe & seek & seem & seed \\
\hline 14 & not & tot & got & pot & hot & lot \\
\hline 15 & vest & test & rest & best & west & nest \\
\hline 16 & pig & pill & pin & pip & pit & pick \\
\hline 17 & back & bath & bad & bass & bat & ban \\
\hline 18 & way & may & say & pay & day & gay \\
\hline 19 & pig & big & dig & wig & rig & fig \\
\hline 20 & pale & pace & page & pane & pay & pave \\
\hline 21 & cane & case & cape & cake & came & cave \\
\hline 22 & shop & mop & cop & top & hop & pop \\
\hline 23 & coil & oil & soil & toil & boil & foil \\
\hline 24 & $\tan$ & $\operatorname{tang}$ & tap & tack & tam & tab \\
\hline 25 & fit & fib & fizz & fill & fig & fin \\
\hline 26 & same & name & game & tame & came & fame \\
\hline 27 & peel & reel & feel & eel & keel & heel \\
\hline 28 & hark & dark & mark & bark & park & lark \\
\hline 29 & heave & hear & heat & heal & heap & heath \\
\hline 30 & cup & cut & cud & cuff & cuss & cud \\
\hline 31 & thaw & law & raw & paw & jaw & saw \\
\hline 32 & pen & hen & men & then & den & ten \\
\hline 33 & puff & puck & pub & pus & pup & pun \\
\hline 34 & bean & beach & beat & beak & bead & beam \\
\hline 35 & heat & neat & feat & seat & meat & beat \\
\hline 36 & dip & sip & hip & tip & lip & rip \\
\hline 37 & kill & kin & kit & kick & king & kid \\
\hline 38 & hang & sang & bang & rang & fang & gang \\
\hline 39 & took & cook & look & hook & shook & book \\
\hline 40 & mass & math & map & mat & $\operatorname{man}$ & $\operatorname{mad}$ \\
\hline 41 & ray & raze & rate & rave & rake & race \\
\hline 42 & save & same & sale & sane & sake & safe \\
\hline 43 & fill & kill & will & hill & till & bill \\
\hline 44 & sill & sick & sip & sing & sit & $\sin$ \\
\hline 45 & bale & gale & sale & tale & pale & male \\
\hline 46 & wick & sick & kick & lick & pick & tick \\
\hline 47 & peace & peas & peak & peach & peat & peal \\
\hline 48 & bun & bus & but & bug & buck & buff \\
\hline 49 & sag & sat & sass & sack & sad & sap \\
\hline 50 & fun & sun & bun & gun & run & nun \\
\hline
\end{tabular}


Gy. Wersényi-Acta Technica Jaurinensis, Vol. 7., No. 3., pp. 294-309, 2014

Table 5. The Hungarian corpus for MRT - 1

\begin{tabular}{|c|c|c|c|c|c|c|}
\hline 1. & bak & rak & lak & jak & csak & (vak, nyak) \\
\hline 2. & far & kar & mar & tar & var & \\
\hline 3. & bab & hab & $\mathrm{rab}$ & $\mathrm{zab}$ & & (tab) \\
\hline 4. & fagy & hagy & nagy & vagy & zagy & \\
\hline 5. & dúl & gyúl & múl & nyúl & túl & (fúl) \\
\hline 6. & bér & dér & fér & kér & mér & (vér) \\
\hline 7. & bor & kor & por & sor & szor & (tor) \\
\hline 8. & bél & cél & dél & fél & szél & (gél, kél, nyél, tél, vél) \\
\hline 9. & bör & ször & Győr & tör & kőr & (csőr) \\
\hline 10. & bal & dal & fal & hal & nyal & \\
\hline 11. & bír & hír & nyír & pír & sír & (szír, zsír) \\
\hline 12. & bók & csók & jók & pók & szók & \\
\hline 13. & hús & bús & dús & szús & & (kús) \\
\hline 14. & búr & dúr & fúr & szúr & túr & (zsúr) \\
\hline 15. & bár & cár & már & kár & nyár & (gyár, jár, pár, sár, tár, vár) \\
\hline 16. & bál & tál & sál & hál & nyál & \\
\hline 17. & csür & kür & szür & tür & zür & \\
\hline 18. & fát & gát & lát & hát & tát & \\
\hline 19. & búg & húg & lúg & rúg & súg & (zúg) \\
\hline 20. & cser & per & ver & mer & nyer & (szer, jer) \\
\hline 21. & kel & lel & jel & nyel & & \\
\hline 22. & kell & mell & Tell & Bell & & \\
\hline 23. & hall & vall & gall & & & \\
\hline 24. & szenny & genny & menny & kenj & menj & \\
\hline 25. & matt & katt & patt & csatt & jatt & \\
\hline 26. & sakk & pakk & cakk & makk & lakk & (fakk, vakk) \\
\hline
\end{tabular}


Gy. Wersényi-Acta Technica Jaurinensis, Vol. 7., No. 3., pp. 294-309, 2014

Table 6. The Hungarian corpus for MRT - 2

\begin{tabular}{|c|c|c|c|c|c|c|}
\hline 1. & bak & buk & bók & bök & búk & \\
\hline 2. & lap & láp & lep & lép & lop & \\
\hline 3. & kar & kár & kér & kür & kór & (kör, kőr) \\
\hline 4. & mar & már & mér & mer & mór & \\
\hline 5. & $\operatorname{tar}$ & tár & tor & tér & tür & (tőr) \\
\hline 6. & bár & bér & bor & bór & bör & \\
\hline 7. & tál & tél & tol & tel & túl & \\
\hline 8. & fal & fel & fél & fúl & fül & \\
\hline 9. & pár & por & per & pír & pér & \\
\hline 10. & rag & rág & rúg & rég & rög & \\
\hline 11. & var & vér & ver & vár & & \\
\hline 12. & vaj & váj & vej & & & \\
\hline
\end{tabular}

Table 7. The Hungarian corpus for MRT - 3

\begin{tabular}{|c|c|c|c|c|c|c|}
\hline 1. & báb & báj & bál & bán & bár & \\
\hline 2. & gél & gém & gén & gép & géz & \\
\hline 3. & fém & fél & fék & fér & fény & \\
\hline 4. & táv & tán & tár & tál & táp & \\
\hline 5. & tény & tér & tép & tét & tél & \\
\hline 6. & szem & szel & szer & szesz & szenny & \\
\hline 7. & len & les & lesz & lep & lel & (leg, LED) \\
\hline 8. & góc & gój & gól & gót & gór & \\
\hline 9. & szám & szár & száz & szák & száj & (szád, szász) \\
\hline 10. & mák & már & más & máz & máj & (mál) \\
\hline 11. & rám & rád & rác & rák & ráz & (rát, rág) \\
\hline 12. & csak & csal & csat & csap & csaj & \\
\hline 13. & dúc & dúl & dúr & dús & & \\
\hline 14. & hab & had & haj & hal & has & \\
\hline 15. & jel & jem & jen & jer & jegy & \\
\hline 16. & kéj & kél & kém & kén & kér & \\
\hline 17. & pék & pép & Pér & pénz & Pécs & \\
\hline 18. & rég & rém & rés & rész & rét & (rév, réz) \\
\hline 19. & vad & vaj & vak & van & var & (vas) \\
\hline 20. & kés & kéz & kép & kész & két & \\
\hline 21. & csel & csen & cser & csepp & & \\
\hline
\end{tabular}

